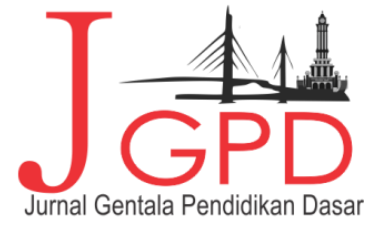

Artikel Penelitian

\title{
Pene rapan Model Pembelajaran Inkuiri untuk Meningkatkan Kemampuan Matematis pada Materi Pengolahan Data Sis wa Kelas V A SDN 61/X Talang Babat
}

\section{Jazimah}

\section{SD Negeri 61/X Talang Babat Kec. Muara Sabak Barat, Jambi, Indonesia}

\begin{tabular}{ll}
\hline Informasi Artikel & ABSTRAK \\
Ditinjau : 7 Mar 2020 & Penelitian ini bertujuan untuk mengetahui kemampuan matematis \\
Direvisi : 18 April 2020 & materi pengolahan data melalui model pembelajaran inkuiri pada \\
Terbit Online : 1 Juni 2020 & siswa kelas V A SD Negeri 61/X Talang Babat. Penelitian ini \\
& merupakan penelitian tindakan kelas (PTK). Penelitan ini terdiri \\
& dari 3 siklus dan setiap siklus terdapat satu kali pertemuan. Tahapan \\
& setiap siklus adalah tahap perencanaan, pelaksanaan, observasi dan \\
Kata Kunci & refleksi tindakan. Subjek penelitian adalah siswa kelas V A SD \\
Kemampuan & Negeri 61/X Talang Babat tahun ajaran 2018/2019 sebanyak 32 \\
matematis, Model & orang siswa. Data penelitian ini adalah teks dan angka tentang \\
Pembelajaran, Inkuiri & kemampuan siswa dalam materi pengolahan data. Data \\
& dikumpulkan melalui observasi dan tes. Hasil penelitian \\
Korespondensi & menyebutkan adanya peningkatan kemampuan siswa kelas V A SD \\
e-mail : & Negeri Talang Babat pada materi pengolahan data melalui model \\
jazimah06@gmail.com & pembelajaran inkuiri. Kriteria keberhasilan penelitian adalah 80\% \\
& nilai tersebut diperoleh pada siklus ke-tiga. Peningkatan nilai dari \\
& siklus pertama sampai ketiga adalah 66 \% menjadi 78\%, dan \\
& menjadi 88\%. Hasil refleksi siklus pertama belum mampu mencapai \\
& kriteria keberhasilan dikarenakan belum terbiasa menerapkan \\
& model pembelajaran inkuiri. Jumlah siswa yang mencapai kriteria \\
& keberhasian pada siklus ketiga adalah 28, yang belum mencapai \\
& adalah 4 siswa. Berdasarkan hasil penelitian maka dapat \\
& disimpulkan bahwa model inkuiri dapat meningkatkan kemampuan \\
& matematis siswa kelas V A SD Negeri 61/X Talang Babat materi \\
& pengolahan data. \\
\hline
\end{tabular}

DOI : https://doi.org/10.22437/gentala.v5i1.9428

\section{PENDAHULUAN}

Berdasarkan Peraturan Mentri Pendidikan dan Kebudayaan Republik Indonesia No 57 Tahun 2014 menyatakan bahwa kecakapan atau kemahiran matematika merupakan bagian dari kecakapan hidup yang harus dimiliki terutama dalam pengembangan penalaran, komunikasi dan pemecahan masalah yang dihadapi siswa dalam kehidupan sehari-hari. Matematika merupakan ilmu universal yang mendasari perkembangan ilmu pengetahuan modern, mempunyai peran yang penting dalam berbagai disiplin ilmu dan memajukan daya piker manusia. Perkembangan pesat dibidang teknologi, informasi dan komunikasi dewasa ini 


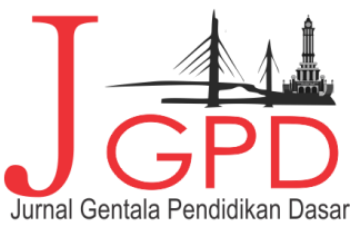

JURNAL GENTALA PENDIDIKAN DASAR Vol.5 No. I Juni 2020, Halaman 91-I09 P-ISSN : 2614-7092, E-ISSN : 2621-96II Terbit Online Pada Laman Web : hittp://online-journal.unja.ac.id/index.php/gentala email : penyunting.jurnal.g-pgsd国unja.ac.id

juga dilandasi oleh perkembangan ilmu matematika. Untuk menguasai dan menciptakan teknologi dimasa depan diperlukan penguasaaan matematika yang kuat sejak dini.

Matematika merupakan salah satu mata pelajaran yang membutuhkan keterlibatan siswa secara langsung agar dapat memahami konsep-konsep dasar materi Matematika. Ini menyebabkan siswa mengalami kesulitan memahami materi karena guru tidak pandai dalam memilih strategi pembelajaran yang cocok yang dapat melibatkan siswa secara langsung dalam proses pembelajaran. Matematika itu terorganisasikan dari unsur-unsur yang tidak didefinisikan, definisi-definisi,aksioma-aksioma, dan dalil-dalil, dimana dalil-dalil setelah dibuktikan kebenarannya berlaku secara umum, karena itulah matematika sering disebut ilmu deduktif disebut ilmu deduktif (Ruseffendi 1989, dalam Karso2002:1.39). Sedangkan menurut Susanto (2013:186) Pembelajaran matematika adalah proses belajar mengajar yang dibangun oleh guru untuk mengembangkan kreatifitas berfikir siswa yang dapat meningkatkan kemampuan berfikir siswa serta dapat meningkatkan kemampuan mengkonstruksi pengetahuanbaru sebagai upaya meningkatkan penguasaan yang baik terhadap materi matematika.

Pembelajaran matematika adalah proses pemberian pengalaman belajar kepada peserta didik melalui serangkaian kegiatan yang terencana sehingga peserta didik peserta didik memperoleh kompetensi tentang bahan matematika yang dipelajari. Sebagi pengetahuan matematika mempunyai ciri -ciri khusus antara lain abstrak, deduktif, konsisten, hierarkis, dan logis.Menurut (Soedjadi 1999 dalam Muhsetyo 2010:1.2) menyatakan bahwa keabstrakan matematika karena obyek dasarnya abstrak, yaitu fakta, konsep, operasi, dan prinsip. Ciri keabstrakan matematika beserta ciri lainya yang tidak sederhana menyebabkan matematika tidak mudah untuk dipelajari. Karena itu banyak siswa yang mengatakan bahwa matematika itu sulit dan mereka tidak tertarik terhadap matematika.

Dari pendapat ahli diatas bisa kita simpulkan bahwa matematika adalah ilmu yang abstrak. Untuk dapat memahami hubungan serta struktur yang ada dalam matematika diperlukan penguasaan tentang konsep yang ada dalam matematika.

Agar pembelajaran matematika dapat mencapai kompetensi yang dinginkan maka perlu dirancang model pembelajaran yang sesuai dengan perkembangan intelektual peserta didik sehingga pembelajaran menjadi sesuatu yang menarik. Sesuai dengan karakteristik perkembangan anak SD yang suka berkelompok maka guru perlu memilih model pembelajaran kelompok yang memiliki aturan-aturan tertentu. Menurut Gatot Muhsetyo dkk 


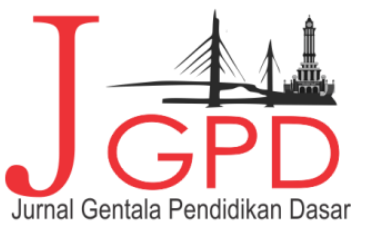

JURNAL GENTALA PENDIDKAN DASAR Vol.5 No. I Juni 2020, Halaman 91--109 P-ISSN : 2614-7092, E-ISSN : 2621-96II

Terbit Online Pada Laman Web : hittp://online-journal.unja.ac.id/index.php/gentala email : penyunting.jurnal.g-pgsd回unja.ac.id

(2010:1.26) Komponen yang menentukan ketercapaian kompetensi adalah penggunaan strategi pembelajaran yang sesuai dengan :

1. Topik yang sedang dibicarakan.

2. Tingkat perkembangan intelektual peserta didik.

3. Prinsip dan teori belajar

4. Keterlibatan aktif peserta didik.

5. Keterkaitan dengan kehidupan peserta didik sehari-hari

6. Pengembangan matematis.

7. Pemahaman dan penalaran matematika

Untuk kelas $\mathrm{V}$ jumlah alokasi waktu untuk mata pelajaran Matematika yaitu sebanyak enam jam dalam satu minggu. Beban belajar kegiatan tatap muka per jam pembelajaran masing-masing satuan pendidikan untuk kelas $\mathrm{V}$ berlangsung selama 35 menit dan jumlah jam pembelajaran tatap muka per minggu adalah 36 jam pembelajaran.

Sesuai yang tercantum dalam Standar Isi tahun 2006 matapelajaran matematika bertujuan agar peserta didik memiliki kemampuan sebagai berikut :

1. Memahami konsep matematika, menjelaskan keterkaitan antar konsep dan mengaplikasikan konsep atau algoritma, secara lues, akurat, efesien dan tepat, dalam pemecahan masalah.

2. Menggunakan penalaran pada pola da sifat, melakukan manipulasi matematika dalam membuat generalisasi, menyusun bukti, atau menjelaskan gagasan dan pernyataan matemetika.

3. Memecahkan masalah yanga meliputi kemampuan memahami masalah, merancang model matematika, menyesuaikan model dan menafsirkan solusi yang diperoleh.

4. Mengomunikasikan gagasan dengan simbol, tabel, diagram, atau media lain untuk memperjelas keadaan atau masalah.

5. Memiliki sikap menghargai kegunaa matemetika dalam kehidupan, yaitu memiliki rasa ingin tahu, perhatian dan minat dalam mempelajari matematika, serta sikap ulet dan rasa percaya diri dalam pemecahan masalah.

Untuk mencapai tujuan pembelajaran mata pelajaran matematika tersebut, seorang guru hendaknya dapat menciptakan kondisi dan situsi pembelajaran yang memungkinkan siswa aktif membentuk, menemukan, dan mengembangkan pengetahuannya. Kemudian siswa dapat membentuk makna dari bahan- bahan pelajaran melalui suatu proses belajar dan 


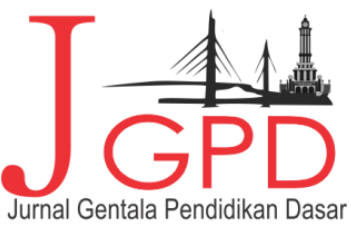

JURNAL GENTALA PENDIDKAN DASAR Vol.5 No. I Juni 2020, Halaman 91-I09 P-ISSN : 2614-7092, E-ISSN : 2621-96II

Terbit Online Pada Laman Web : hittp://online-journal.unja.ac.id/index.php/gentala email : penyunting.jurnal.g-pgsd国unja.ac.id

menyusunnya dalam ingatannya sewaktu-waktu dapat diproses dan dikembangkan lebih lanjut.

Pelajaran matematika perlu diajarkan untuk membekali siswa dengan kemampuan berfikir logis sistematis, kritis, kreatif dan dapat bekerjasama. Kemampuan ini berguna bagi siswa agar dapat memperoleh, mengelola dan memanfaatkan semua informasi dilingkungannya untuk dapat bertahan dan melanjutkan kehidupannya.

Siswa SD pada umumnya telah mengetahui pengumpulan data dalam kehidupan sehariharinya. Pengumpulan data bagi siswa SD telah akrab dengan kehidupan sehari-hari. Penggunaan pengolahan data harus memperhatikan dan menggunkan obyek yang akan dikumpul. Dalam pembahasan di kelas $\mathrm{V}$ ini materi yang dibahas tentang pengumpulan data dan ditampilkan dalam bentuk tabel, diagram batang, diagram gambar, dan diagram lingkaran ( Erlangga 2016:112 ). Hasil observasi yang dilakukan pada awal pra penelitian di SD 61/X Talang Babat kelas V A pada materi pengolahan data, siswa kurang maksimal dalam mengejakan soal.

Berdasarakan analisis yang didasari suatu bukti nyata berdasarkan pengalaman sendiri saat melakukan obeservasi tersebut, ternyata ketidaktepatan guru menggunakan metode dan media, guru aktif siswa pasif, guru pemain dan siswa penonton dalam pembelajaran, menyebabkan rendahnya pemahaman siswa terhadap materi yang disajikan dan berimbas kepada rendahnya kemampuan matematis siswa. Hal tersebut ditandai oleh rendahnya nilai yang diperoleh siswa dalam menyelesaikan soal-soal yang diberikan guru.

Mengingat pembelajaran di Sekolah Dasar merupakan awal kegiatan wajib belajar dan merupakan jenjang pedidikan yang ditempuh dalam waktu paling lama, maka agar pencapaian hasil belajar dapat dicapai secara optimal, guru perlu memperhatikan karakteristik siswa Sekolah Dasar. Menurut Permendiknas Nomor 57 Tahun 2014, karakteristik yang dimiliki anak-anak usia SD pada umumnya adalah :

a) Senang bergerak

Berbeda dengan orang dewasa yang betah duduk berjam-jam, anak-anak usia SD lebih senang bergerak. Anak-anak usia ini dapat duduk dengan tenang maksimal sekitar 30 menit.

b) Senang bermain

Dunia anak memang dunia bermain yang penuh kegembiraan, demikian juga dengan anakanak usia SD, mereka masih sangat senang bermain. Apalagi anak-anak SD kelas rendah. 


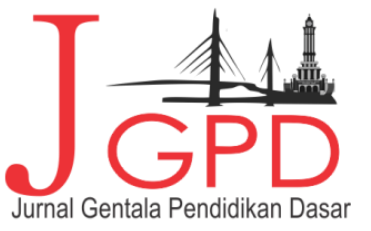

JURNAL GENTALA PENDIDKAN DASAR Vol.5 No. I Juni 2020, Halaman 91--109 P-ISSN : 2614-7092, E-ISSN : 2621-96II

Terbit Online Pada Laman Web : hittp://online-journal.unja.ac.id/index.php/gentala email : penyunting.jurnal.g-pgsd回unja.ac.id

c) Senang melakukan sesuatu secara langsung

Anak-anak usia SD akan lebih mudah memahami pelajaran yang diberikan guru jika ia dapat mempraktikkan sendiri secara langsung pelajaran tersebut.

d) Senang bekerja dalam kelompok

Pada usia SD, anak-anak mulai intens bersosialisasi. Pergaulan dengan kelompok sebaya, akan membuat anak usia SD bisa belajar banyak hal, misalnya setia kawan, bekerja sama, dan bersaing secara sehat.

Model pembelajaran inkuiri cocok untuk karakteristik siswa dan kemampuan matematis siswa pada materi pengolahan data. Model pembelajaran adalah suatu kerangka konseptual atau pola yang melukiskan prosedur secara sistematis dalam mengorganisasikan pengalaman belajar untuk mencapai tujuan belajar tertentu dan berfungsi sebagai pedoman bagi para perancang pembelajaran dan para pengajar dalam merencanakan dan melaksanakan aktivitas pembelajaran, (Winataputra dalam Noeraida, dkk, $2016: 8$ ). Sementara itu, Joyce et al dalam Noeraida, dkk, (2016 : 8) mengemukakan bahwa model pembelajaran merupakan kerangka berpikir yang mengarahkan seseorang merancang dan melaksanakan pembelajaran di kelas serta membimbing siswa belajar di kelas sehingga interaksi belajar dan mengajar lebih terarah. Berdasarkan pendapat di atas dapat disimpulkan bahwa model pembelajaran itu adalah gambaran proses pembelajaran dari awal sampai akhir yang dirancang oleh guru.

Joyce dan Weil dalam Winataputra (2001 : 4-8) mengelompokkan model-model pembelajaran ke dalam empat kategori, yakni:

a) Kelompok model pengolahan informasi atau the information processing family

b) Kelompok model personal atau the personal family

c) Kelompok model sosial atau the sosial family

d) Kelompok model sistem perilaku atau the behavioral system family

Kelompok model pengolahan informasi adalah model :

1. Pencapaian konsep (concept attainment)

2. Berpikir induktif (induktive thinking)

3. Latihan penelitian (inquiry training)

4. Pemandu awal (advance organizers)

5. Memorisasi (memorization)

6. Pengembangan intelek (developing intellect)

7. Penelitian ilmiah (scientific inquiry 
Kelompok model personal adalah model :

1. Pengajaran tanpa arahan (non directive teaching)

2. Sinektiks (synectics model)

3. Latihan kesadaran (awareness training)

4. Pertemuan kelas (classroom meeting)

Kelompok model sosial meliputi model seperti berikut :

1. Investigasi kelompok (group investigasion)

2. Bermain peran (role playing)

3. Penelitian yurisprudential (jurisprudential inquiry)

4. Latihan laboratoris (laboratory training)

5. Penelitian ilmu sosial (social scienceinquiry)

Kelompok model sistem perilaku yaitu :

1. Belajar tuntas (maatery learning)

2. Pembelajaran langsung (direct instruction)

3. Belajar kontrol diri (learning self control)

4. Latihan pengembangan keterampilan dan konsep (training for skill and concept development)

5. Latihan asertif (assertive training)

Model Pembelajaran inkuiri Suchman dalam Zubaidah, dkk (2013 : 103) mengartikan inkuiri sebagai suatu pencarian kebenaran, informasi, atau pengetahuan. Selanjutnya Joyce dan Well dalam Zubaida, dkk (2013 : 103) mengemukakan bahwa inti dari pembelajaran inkuiri adalah melibatkan siswa dalam masalah penyelidikan nyata dengan menghadapkan mereka dengan cara penyelidikan (investigasi), membantu mereka mengidentifikasi masalah konseptual atau metodologis dalam wilayah investigasi dan meminta mereka merancang mengatasi masalah.

Menurut Al-Cho Ong dkk, dalam Zubaidah, dkk (2013 : 103 - 104) pembelajaran berbasis inkuiri adalah pencapaian hasil belajar melalui pencarian informasi, pengetahuan diperoleh melalui pengajuan pertanyaan. Selanjutnya dikemukakan inkuiri adalah berbagai kegiatan termasuk melakukan observasi, mengajukan pertanyaan, mencari dan menggunakan informasi untuk mengetahui dengan jelas peristiwa melalui percobaan, menggunakan alat untuk mengumpulkan, menganalisa, dan menafsirkan data, mengajukan pertanyaan, menjelaskan, dan memprediksi dan mengkomunikasikan hasil. 


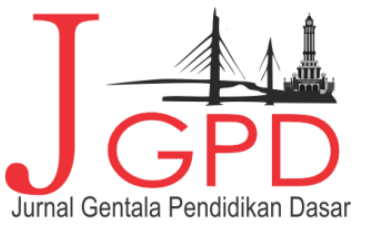

JURNAL GENTALA PENDIDKAN DASAR Vol.5 No. I Juni 2020, Halaman 91--109 P-ISSN : 2614-7092, E-ISSN : 2621-96II

Terbit Qnline Pada Laman Web : hittp://online-journal.unja.ac.id/index.php/gentala email : penyunting.jurnal.g-pgsd国unja.ac.id

Menurut Banchi dan Bell dalam Zubaidah, dkk (2013 : 109) inkuiri ada 4 tingkatan dari tingkat bawah sampai tinggi, yaitu :

1. Inkuiri konfirmasi (confirmation inquiry)

2. Inkuiri terstruktur (struktured inquiry)

3. Inkuiri terbimbing (guided niquiry)

4. Inkuiri terbuka (open inquiry)atau inkuiri penuh (full inquiry).

Berbagai tingkatan inkuiri tersebut dibedakan berdasarkan tingkat kemandirian siswa dalam merumuskan masalah, menyusun prosedur pemecahan masalah, dan merumuskan solusi. Berikut ringkasan tingkatan inkuiri menurut Banchi dan Bell dalam Zubaidah, dkk (2013 : 111).

Tabel 1 Tingkatan Inkuiri Menurut Banchi dan Bell

\begin{tabular}{|c|c|c|c|c|}
\hline No & Tingkatan Inkuiri & Masalah & Prosedur & Solusi \\
\hline 1. & $\begin{array}{l}\text { Inkuiri informasi (confirmation inquiry) } \\
\text { Siswa menkonfirmasi prinsip melalui kegiatan } \\
\text { ketika hasilnya sudah diketahui sebelumnya }\end{array}$ & $\mathrm{V}$ & $\mathrm{V}$ & V \\
\hline 2. & $\begin{array}{l}\text { Inkuiri terstruktur (structured inquiry) } \\
\text { Siswa menyelidiki pertanyaan yang disajikan guru } \\
\text { melalui prosedur yang sudah ditentukan }\end{array}$ & $\mathrm{v}$ & $\mathrm{V}$ & \\
\hline 3. & $\begin{array}{l}\text { Inkuiri terbimbing (guided inquiry) } \\
\text { Siswa menyelidiki pertanyaan yang disajikan guru } \\
\text { dengan menggunakan prosedur yang dirancang } \\
\text { siswa }\end{array}$ & $\mathrm{V}$ & & \\
\hline 4. & $\begin{array}{l}\text { Inkuiri terbuka (open inquiry) } \\
\text { Siswa menyelidiki pertanyaan yang dirumuskan } \\
\text { oleh siswa sendiri melalui prosedur yang dirancang } \\
\text { oleh siswa }\end{array}$ & & $\mathrm{V}$ & \\
\hline
\end{tabular}

Jenis model pembelajaran inkuiri yang peneliti gunakan pada PTK ini adalah inkuiri terstruktur karena dianggap lebih cocok dengan siswa SMP, sesuai dengan pendapat Banchi dan Bell dalam Zubaidah, dkk (2013 : 110) yang mengatakan inkuiri konfirmasi dan terstruktur dianggap inkuiri tingkat rendah, pada umumnya diterapkan di pendidikan tingkat dasar (SD dan SMP).

Tahapan (sintaks) yang digunakan oleh guru dalam merancang pembelajaran berbasis inkuiri menurut Joyce dan Well dalam Zubaidah, dkk (2013 : 119) sebagai berikut

a) Identifikasi dan penetapan ruang lingkup masalah

b) merencanakan dan memprediksi hasil

c) Penyelidikan untuk pengumpulan data

d) Interpretasi dada dan mengembangkan kesimpulan 


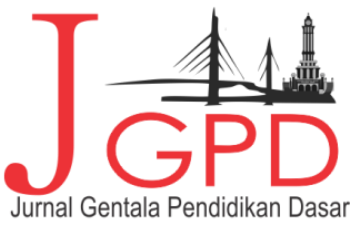

JURRAL GENTALA PENDIDIKAN DASAR Vol.5 №. I Juni 2020, Halaman 9l-I0马 P-ISSN : 2614-7092, E-ISSN : 2621-9611

Terbit Online Pada Laman Web : http://online-juurnal.unja.ac.id/index.php/gentala email : peny unting.jurnal.g-pgsd回unja.ac.id

e) melakukan refleksi.

Kemampuan matematis berkaitan erat dengan hasil belajar siswa. Pada kurikulum 2006, penilaian didefenisikan sebagai penilaian pendidikan yaitu proses pengumpulan dan pengolahan informasi untuk menentukan pencapaian hasil belajar siswa (Kemendiknas dalam Sulaeman, 2016 : 7) Tujuan penilaian adalah mengetahui tingkat pencapaian kompetensi yang diperoleh peserta didik, serta digunakan sebagai bahan penyusun laporan kemampuan hasil belajar dan memperbaiki proses pembelajaran, (Sulaeman, 2016 : 12).

Hasil belajar merupakan sesuatu yang diperoleh siswa setelah mengikuti kegiatan belajar. Hasil belajar digunakan sebagai gambaran penguasaan siswa dan keberhasilan suatu program yang diterapkan serta ketuntasan belajar siswa. Penilaian hasil belajar mempunyai tujuan tersendiri dalam pembelajaran. Arikunto (2008:11) menyatakan bahwa tujuan penilaian hasil belajar adalah untuk dapat mengetahui sejauh mana suatu program berhasil diterapkan. Hasil belajar diperoleh melalui tes, baik secara lisan maupun tertulis. Hasil belajar juga merupakan suatu indikator yang penting dapat digunakan dalam melihat keberhasilan/penguasaan konsep yang telah dipelajari dan ketuntasan belajar siswa.

Menurut Dimyati dan Mudjiono (2006:200) Hasil belajar adalah tingkat keberhasilan yang dicapai siswa setelah mengikuti suatu kegiatan pembelajaran dimana tingkat keberhasilan tersebut kemudian ditandai dengan standar nilai berupa huruf, kata, simbol.

Hasil belajar menurut Ahmad Susanto (2014: 5) yaitu perubahan-perubahan yang terjadi pada diri siswa, baik yang menyangkut aspek kognitif, afektif, dan psikomotor sebagai hasil dari kegiatan belajar. Secara sederhana yang dimaksud dengan hasil belajar siswa adalah kemampuan yang diperoleh anak setelah melalui kegiatan belajar. Karena belajar itu sendiri merupakan suatu proses dari seseorang yang berusaha untuk memperoleh suatu bentuk perubahan perilaku yang relative menetap.

Hasil belajar merupakan perubahan perilaku yang diperoleh siswa setelah mengalami aktivitas belajar. Oleh karena itu apabila siswa mempelajari pengetahuan tentang konsep, maka perubahan perilaku yang diperoleh adalah berupa penguasaan konsep. Dalam pembelajaran perubahan perilaku yang harus dicapai oleh siswa setelah melaksanakan aktivitas belajar dirumuskan dalam tujuan pembelajaran.

Hasil belajar sebagaimana telah dijelaskan di atas meliputi pemahaman konsep (aspek kognitif), keterampilan proses (aspek psikomotor), dan sikap siswa (aspek afektif). Untuk lebih jelasnya dapat dijelaskan sebagai berikut : 


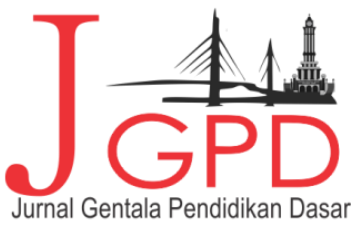

JURRAL GENTALA PENDIDIKAN DASAR Vol.5 №. I Juni 2020, Halaman 9l-I0马 P-ISSN : 2614-7092, E-ISSN : 2621-S6611

Terbit Online Pada Laman W eb : http://online-juurnal.unja.ac.id/index.php/gentala email : peny unting.jurnal.g-pgsd国unja.ac.id

a) Pemahaman Konsep (aspek kognitif)

Pemahaman menurut Bloom dalam Ahmad Susanto (2014: 6), diartikan sebagai kemampuan untuk menyerap arti dari materi atau bahan yang dipelajari. Pemahaman menurut Bloom ini adalah seberapa besar siswa mampu menerima, menyerap, dan memahami pelajaran yang diberikan oleh guru kepada siswa, atau sejauh mana siswa dapat memahami serta mengerti apa yang ia baca, yang dilihat, yang dialami, ata u yang ia rasakan berupa hasil penelitian atau observasi langsung yang ia lakukan.

b) Keterampilan proses (aspek psikomotor)

Menurut Usman dan Setiawati dalam Ahmad Susanto (2014: 9), mengemukakan bahwa keterampilan proses merupakan keterampilan yang mengarah kepada pembangunan kemampuan mental, fisik, dan social yang mendasar sebagai penggerak kemampuan yang lebih tinggi dalam dirïndividu siswa.

c) Sikap (aspek afektif)

Menurut Lange dalam Azwar dalam Ahmad Susanto (2014: 10), sikap tidak hanya merupakan aspek mental semata, melainkan mencakup pula aspek respon fisik. Jadi, sikap ini harus ada kekompakkan antara mental dan fisik secara serempak.

Faktor-faktor yang mempengaruhi hasil belajar yaitu faktor yang mempengaruhi pencapaian hasil belajar siswa. Menurut (Djaali 2009:99-100) Faktor yang mempengaruhi pencapaian hasil belajar berasal dari diri orang yang belajar dan ada dari luar dirinya.

1. Faktor dari dalam diri

a) Kesehatan

Apabila orang selalu sakit menyebabakan tidak bergairah dalam belajar.

b) Intelegensi

Faktor intelegensi dan bakat besar sekali pengaruhnya terhadap kemajuan belajar

c) Minat dan motivasi

Minat yang besar ( keinginan yang kuat) terhadap sesuatu merupakan modal besar untuk mencapai tujuan. Motivasi merupakan dorongan diri sendiri, umumnya karena kesadaran akan pentingnya sesuatu.Motivasi juda dapat berasal dari luar dirinya yaitu dorongan dari lingkungan misalnya guru dan orang tua.

d) Cara belajar

Perlu diperhatikan teknik belajar, bagaimana bentuk catatan yang dipelajari dan pengaturan waktu belajar, tempat, serta fasilitas belajar lainnya. 


\section{Faktor dari luar diri}

a) Keluarga

Situasi keluarga ( ayah, ibu, saudara, adik, kakak,serta famili) sangat berpengaruh terhadap keberhasilan anak dalam keluarga. Pendidikan orang tua status ekonomi, rumah kediaman, persentase hubungan orang tua ,perkataan, dan bimbingan orang tua mempengaruhi pencapaian belajar anak.

b) Sekolah

Tempat, gedung sekolah, kualitas guru, perangkat instrumen pendidikan lingkungan sekolah, dan rasio guru dan murid perkelas mempengaruhi hasil belajar siswa.

c) Masyarakat

Apabila disekitar tempat tinggal keadaan masyarakat terdiri atas orang-orang berpendidikan, terutama anak-anaknya rata-rata bersekolah tinggi dan moralnya baik, hal ini akan mendorong anak akan lebih giat belajar.

d) Lingkungan sekitar

Bangunan rumah, suasana sekitar, keadaan lalu lintas dan iklim dapat mempengaruhi pencapaian tujuan belajar, sebaiknya tempat-tempat dengan iklim yang sejuk, dapat menunjang proses belajar.

Pendapat yang senada dikemukakan oleh Wasliman dalam Ahmad Susanto (2014: 12), hasil belajar yang dicapai oleh peserta didik merupakan hasil interaksi antara berbagai faktor yang memengaruhi, baik faktor internal maupun faktor eksternal. Secara perinci, uraian mengenai faktor internal dan eksternal, sebagai berikut :

a) faktor internal; faktor internal merupakan factor yang bersumber dari dalam diri peserta didik, yang memengaruhi kemampuan belajarnya. Faktor internal ini meliputi: kecerdasan, minat dan perhatian, motivasi belajar, ketekunan, sikap, kebiasaan belajar, serta kondisi fisik dan kesehatan.

b) Faktor eksternal ; faktor yang berasal dari diri peserta didik yang memengaruhi hasil belajar yaitu keluarga, sekolah, dan masyarakat. Keadaan keluarga berpengaruh terhadap hasil belajar siswa. Keluarga yang morat-marit keadaan ekonominya, pertengkaran suami isteri, perhatian orang tua yang kurang terhadap anaknya, serta kebiasaan sehari-hari berperilaku yang kurang baik dari orang tua dalam kehidupan sehari-hari berpengaruh dalam hasil belajar peserta didik. 


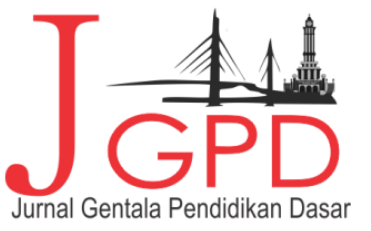

JURNAL GENTALA PENDIDKAN DASAR Vol.5 No. I Juni 2020, Halaman 91--109 P-ISSN : 2614-7092, E-ISSN : 2621-96II Terbit Online Pada Laman Web : hittp://online-journal.unja.ac.id/index.php/gentala email : penyunting.jurnal.g-pgsd国unja.ac.id

Kualitas pengajaran di sekolah sangat ditentukan oleh guru, sebagaimana dikemukakan oleh Wina Sanjaya (2013: 52), bahwa gruru adalah komponen yang sangat menentukan dalam implementasi suatu strategi pembelajaran. Berdasarkan pendapat ini dapat ditegaskan bahwa salah satu faktor eksternal yang sangat berperan memengaruhi hasil belajar siswa adalah guru. Guru dalam proses pembelajaran memegang peranan penting.

Guru sudah berusaha memperbaiki kondisi ini dengan terlibat aktif dalam kelompok kerja guru agar bisa mendiskusikan permasaalahan ini dengan teman sejawat. Bertukar pengalaman, mencari solusi, namun belum membuahkan hasil. Pada prinsipnya model pembelajaran inkuiri ini akan mampu menciptakan suasana atau hubungan baik antara sesama siswa sehingga ada keinginan dan kemauan dari siswa untuk menyaksikan apa yang didemonstrasikan. Selain itu, ketika demonstrasi dilaksanakan, siswa akan mendapatkan gambaran yang jelas tentang materi pelajaran yang sedang diajarkan dan dengan adanya model pembelajaran inkuiri ini, siswa akan lebih giat belajar karena mereka semua berharap tidak ada kendala ketika mereka diminta untuk mendemonstrasikan materi yang dipelajari. (Imas Kurniasih dan Berlin Sani, 2016: 85). Oleh karena itu, peneliti mencoba untuk melakukan penelitian yang berkaitan dengan penggunaan model inkuiri sebagai metode pembelajaran untuk meningkatkan kemampuan matematis siswa, dengan judul penelitian "Penggunaan Model Pembelajaran Inkuiri Pada Materi Pengolahan Data Untuk Meningkatkan Kemampuan Matematis Siswa Kelas VA SDN 61/X Talang Babat Tahun Pelajaran 2018/2019 “.

\section{METODE PENELITIAN}

Tempat dilaksanakannya Penelitian Tindakan Kelas (PTK) ini adalah tempat yang digunakan untuk memperoleh data yang diinginkan. Penelitian ini dilaksanakan di SD Negeri 61/X Talang Babat pada mata pelajaran Matematika di kelas V.A Tahun Pelajaran 2018/2019. Dalam Penelitian Tindakan Kelas (PTK) ini yang menjadi subyek penelitian adalah siswa-siswi Kelas V.A SD Negeri 61/X Talang Babat yang terdiri dari 32 orang di tahun pelajaran 2018/2019 pada mata pelajaran Matematika dengan materi pengolahan data.

Penelitian tindakan secara garis besar, peneliti pada umumnya mengenal adanya empat langkah penting, yaitu pengembangan plan(perencanaan),act (tindakan), observer (pengamatan), dan reflect (perenungan) atau disingkat PAOR, yang dilakukan secara intensif 


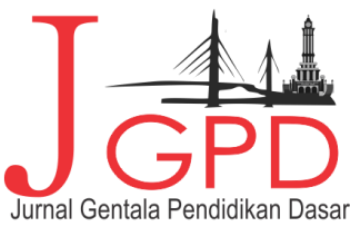

JURNAL GENTALA PENDIDIKAN DASAR Vol.5 No. I Juni 2020, Halaman II-I09 P-ISSN : 2614-7092, E-ISSN : 2621-S6611

Terbit Online Pada Laman Web : http://online-juurnal.unja.ac.id/index.php/gentala email : peny unting.jurnal.g-pgsd国unja.ac.id

dan sistematis atas seseorang yang mengerjakan pekerjaan sehari-harinya (Sukardi, 2010: 212).

Sesuai dengan jenis penelitian yang dipilih, yaitu penelitian tindakan, maka penelitian ini menggunakan model penelitian tindakan dari Kemmis dan Taggart yaitu berbentuk spiral dan saling terkait dari sklus yang satu ke siklus yang berikutnya. Setiap siklus meliputi (perencanaan, tindakan, observasi, dan refleksi). Teknik yang digunakan pada penelitian ini adalah metode tes, metode observasi.

Data yang telah terkumpul perlu dianalisis untuk mengetahui keefektifan model inkuiri dalam pembelajaran. Angka angka tersebut akan menunjukkan tingkat keberhasilan dalam proses pembelajaran. Kriteria Ketuntasan Minimal (KKM) menjadi patokan ketuntasan pembelajaran siswa. Jika nilai yang diperoleh siswa diatas atau sama dengan KKM akan dinyatakan tuntas Langkah analisa data pada penelitian ini adalah sebagai berikut:

1. Nilai dan hasil observasi direkap dalam bentuk tabel.

2. Menghitung nilai rata-rata hasil belajar siswa.

3. Nilai yang diperoleh siswa akan ditentukan ketuntasannya satu persatu

4. Menghitung jumlah siswa yang tuntas dan yang tidak tuntas.

5. Mempresentasekan tingkat ketuntasan siswa

Data kuantitatif berupa hasil belajar siswa yang diperoleh dari hasil Tes siklus I, II, dan III dilakukan dengan perhitungan sebagai berikut:

Skor perolehan

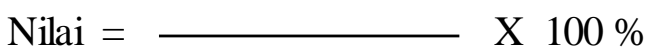

Skor maksimal

\section{HASIL PENELITIAN DAN PEMB AHASAN}

\section{Hasil Penelitian}

Mata pelajaran matematika yang diajarkan di sekolah dasar sebanyak 6 jam per minggu. 1 jam pelajaran lamanya 35 menit dan dilaksanakan sebanyak 3 kali pertemuan perminggu. Dalam satu kali pertemuan dua jam pelajaran. Namun demikian ada saja siswa yang tidak menyukai pelajaran ini, karena beranggapan matematika adalah pelajaran yang sulit.

Deskripsi awal tentang hasil belajar siswa pada semester II (kenaikan kelas pada tahun pelajaran 2018/2019 dapat dilihat pada tabel 2. 


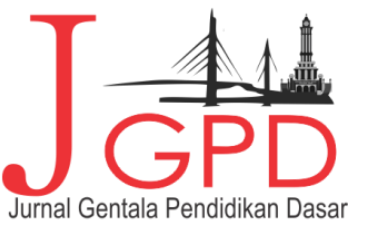

JURNAL GENTALA PENDIDKAN DASAR Vol.5 No. I Juni 2020, Halaman 91--109

P-ISSN : 2614-7092, E-ISSN : 2621-46II

Terbit Online Pada Laman Web : hittp://online-journal.unja.ac.id/index.php/gentala email : penyunting.jurnal.g-pgsd回unja.ac.id

Tabel 2. Hasil Pra Penelitian

\begin{tabular}{|l|l|}
\hline Jumlah & 32 \\
\hline Rata - rata & 64,81 \\
\hline Jumlah Siswa yang Tuntas & 18 \\
\hline $\begin{array}{l}\text { Jumlah Siswa yang tidak } \\
\text { Tuntas }\end{array}$ & 14 \\
\hline Persentase Ketuntasan Siswa & $56 \%$ \\
\hline $\begin{array}{l}\text { Persentase Siswa yang tidak } \\
\text { tuntas }\end{array}$ & $44 \%$ \\
\hline
\end{tabular}

Dari tabel di atas terlihat bahwa hasil belajar kelas V.A pada mata pelajaran Matematika di SD Negeri 61/X Talang Babat masih rendah. Siswa yang tuntas dalam belajar hanya 18 orang siswa atau hanya $56 \%$ dari jumlah keseluruhan siswa, sedangkan jumlah siswa yang tidak tuntas dalam belajar berjumlah 14 orang siswa atau sekitar $44 \%$, selain itu juga untuk nilai rata-rata siswa yaitu 64,81 dan dengan KKM (Kriteria Ketuntasan Minimal) yang telah ditetapkan oleh guru yaitu 70 .

Pelaksanaan siklus I dengan rancangan pembelajaran sebagai berikut:

a) Perencanaan

Rencana Pelaksanaan Pembelajaran (RPP) pada siklus I dirancang dalam satu kali pertemuan dengan alokasi waktu 2 x 35 menit.

RPP berisi : penentuan $\mathrm{KI}, \mathrm{KD}$, materi, indikator, tujuan pembelajaran, skenario pembelajaran, media/sumber belajar, dan penilaian

b) Langkah-langkah skenario pembelajaran :

Tahap Pendahuluan 10 menit Mengadakan apersepsi

Tahap Inti 50 menit:

Siswa memperhatikan penjelasan guru

Siswa memperhatikan demonstrasi yang dilakukan temannya

Tahap Penutup 10 menit:

Siswa mengejakan evaluasi

Memberi tugas rumah sebagai program tindak lanjut

Persiapan sarana dan fasilitas pendukung sarana gambar yang berhubungan dengan data hasil pengukuran.

Mempersiapkan buku bintang untuk siswa yang cepat dan tepat.

c) Mempersiapkan lembar observasi 


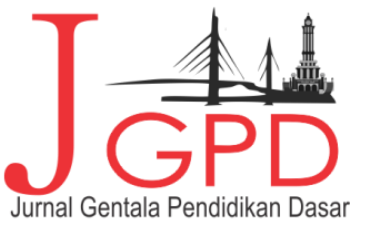

JURNAL GENTALA PENDIDKAN DASAR Vol.5 No. I Juni 2020, Halaman 91--109 P-ISSN : 2614-7092, E-ISSN : 2621-956II

Terbit Online Pada Laman Web : hittp://online-journal.unja.ac.id/index.php/gentala email : penyunting.jurnal.g-pgsd回unja.ac.id

Lembar observasi digunakan untuk mengamati aktifitas guru dalam melaksanakan pembelajaran dengan menggunakan model inkuiri.

d) Refleksi

Tabel 3. Hasil Siklus I

\begin{tabular}{|l|l|}
\hline Jumlah & 32 \\
\hline Rata - rata & 69,56 \\
\hline Jumlah Siswa yang Tuntas & 21 \\
\hline $\begin{array}{l}\text { Jumlah Siswa yang tidak } \\
\text { Tuntas }\end{array}$ & 11 \\
\hline Persentase Ketuntasan Siswa & $66 \%$ \\
\hline $\begin{array}{l}\text { Persentase Siswa yang tidak } \\
\text { tuntas }\end{array}$ & $34 \%$ \\
\hline
\end{tabular}

Dari tabel di atas dapat dijelaskan bahwa dengan menerapkan model inkuiri terlihat bahwa hasil belajar siswa mengalami peningkatan dari nilai test formatif pada kondisi awal. Siswa yang tuntas dalam belajar yaitu dari 18 orang siswa bertambah menjadi 21 orang siswa atau dari $56 \%$ menjadi $66 \%$ berarti peningkatan ini sekitar $10 \%$ dari jumlah keseluruhan siswa. Untuk siswa yang tidak tuntas dalam belajar dari 14 orang siswa berkurang menjadi 11 orang siswa atau dari $44 \%$ menjadi $34 \%$. Berarti mengalami pengurangan sekitar $10 \%$, selain itu nilai rata-rata siswa dari 64,81 menjadi 69,56. Dari nilai di atas dapat disimpulkan bahwa terjadi perubahan/peningkatan nilai siswa.

\section{Rencana pembelajaran siklus II}

a) Perencanaan

Rencana Pelaksanaan Pembelajaran (RPP) pada siklus II dirancang dalam satu kali pertemuan dengan alokasi waktu 2 × 35 menit.

RPP berisi : penentuan $\mathrm{KI}, \mathrm{KD}$, materi, indikator, tujuan pembelajaran, skenario pembelajaran, media/sumber belajar, dan penilaian

b) Langkah-langkah skenario pembelajaran :

Tahap Pendahuluan 10 menit Mengadakan apersepsi

Tahap Inti 50 menit

Siswa memperhatikan penjelasan guru

Siswa melaksanakan demonstrasi dengan bantuan guru

Tahap Penutup 10 menit Siswamengejakan evaluasi 


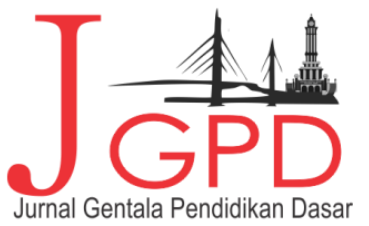

JURNAL GENTALA PENDIDKAN DASAR Vol.5 No. I Juni 2020, Halaman 91--109 P-ISSN : 2614-7092, E-ISSN : 2621-956II

Terbit Online Pada Laman Web : hittp://online-journal.unja.ac.id/index.php/gentala email : penyunting.jurnal.g-pgsd回unja.ac.id

Memberi tugas rumah sebagai program tindak lanjut

Persiapan sarana dan fasilitas pendukung seperti gambar yang berhubungan dengan pengumpulan data.

Mempersiapkan buku bintang untuk siswa yang cepat dan tepat.

c) Mempersiapkan lembar observasi

Lembar observasi digunakan untuk mengamati kegiatan guru dan keaktifan siswa dalam pembelajaran dengan metode kerja kelompok.

Tabel 4. Hasil Siklus II

\begin{tabular}{|l|l|}
\hline Jumlah & 32 \\
\hline Rata - rata & 73,71 \\
\hline Jumlah Siswa yang Tuntas & 25 \\
\hline $\begin{array}{l}\text { Jumlah Siswa yang tidak } \\
\text { Tuntas }\end{array}$ & 7 \\
\hline Persentase Ketuntasan Siswa & $78 \%$ \\
\hline $\begin{array}{l}\text { Persentase Siswa yang tidak } \\
\text { tuntas }\end{array}$ & $22 \%$ \\
\hline
\end{tabular}

Siswa yang tuntas dalam belajar yaitu dari 21 orang siswa bertambah menjadi 25 orang siswa atau dari $66 \%$ menjadi $78 \%$ berarti peningkatan ini sekitar $12 \%$ dari jumlah keseluruhan siswa. Untuk siswa yang tidak tuntas dalam belajar dari 11 orang siswa berkurang menjadi 7 orang siswa atau dari $34 \%$ menjadi $22 \%$. Berarti terjadi pengurangan sekitar $12 \%$, selain itu nilai rata-rata siswa dari 69,56 menjadi 73,71. Dari nilai di atas dapat disimpulkan bahwa kembai terjadi perubahan/peningkatan nilai siswa dengan niai rata-rata keas mengalami peningkatan dan melampaui nilai KKM (Kriteria Ketuntasan Minimal) yang telah ditentukan oeh guru, yaitu 70 .

Rencana pembelajaran siklus III

a) Perencanaan

Rencana Pelaksanaan Pembelajaran (RPP) pada siklus II dirancang dalam satu kali pertemuandengan alokasi waktu 2 x 35 menit.

RPP berisi : penentuan KI, KD, materi, indikator, tujuan pembelajaran, skenario pembelajaran, media/sumber belajar, dan penilaian

b) Langkah-langkah skenario pembelajaran :

Tahap Pendahuluan 10 menit. Mengadakan apersepsi. 


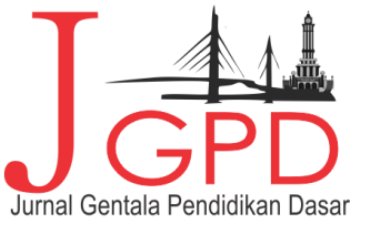

Tahap Inti 50 menit

Siswa memperhatikan penjelasan guru.

Siswa melaksanakan demonstrasi dibawah bimbingan guru.

Tahap Penutup 10 menit. Siswamengejakan evaluasi .

Memberi tugas rumah sebagai program tindak lanjut.

Persiapan sarana dan fasilitas pendukung .

Mempersiapkan buku bintang untuk siswa yang cepat dan tepat.

c) Mempersiapkan lembar observasi.

Lembar observasi digunakan untuk mengamati kegiatan guru dalam pelaksanaan pembelajaran dengan model demonstrasi.

Tabel 4. Hasil Siklus III

\begin{tabular}{|l|l|}
\hline Jumlah & 32 \\
\hline Rata - rata & 74,25 \\
\hline Jumlah Siswa yang Tuntas & 28 \\
\hline $\begin{array}{l}\text { Jumlah Siswa yang tidak } \\
\text { Tuntas }\end{array}$ & 4 \\
\hline Persentase Ketuntasan Siswa & $88 \%$ \\
\hline $\begin{array}{l}\text { Persentase Siswa yang tidak } \\
\text { tuntas }\end{array}$ & $12 \%$ \\
\hline
\end{tabular}

Dari kemampuan matematis siswa pada materi pengolahan data dari siklus III di kelas V A SDN 61/X Talang Babat, pada pelajaran Matematika diatas terlihat kenaikan jumlah siswa yang memahami pelajaran dari 32 siswa, 4 orang siswa tidak tuntas dan 28 orang siswa yang mencapai kriteria ketuntasan minimal. Angka ini menunjukkan bahwa siswa yang berhasil mencapai KKM sudah meningkat dari data siklus II, $78 \%$ menjadi $88 \%$ pada siklus III, dan yang tidak mencapai KKM berkurang dari $22 \%$ menjadi $12 \%$. Dan nilai rata-rata kelas terjadi perubahan dari 73,71 naik menjadi 74,85 . Hal ini menunjukkan adanya perubahan pemahaman terhadap materi pelajaran menjadi semakin membaik.

\section{Pembahasan}

Berdasarkan hasil penelitian, terjadi peningkatan dari kemampuan matematis melalui model pembelajaran inkuiri. Peningkatan terjadi bertahap dari siklus I sampai siklus III. Berdasarkan hasil observasi dan nilai postest pada siklus I belum memenihi kriteria keberhasilan, peneliti masih perlu untuk melanjutkan kegiatan penelitian dan melanjutkan 


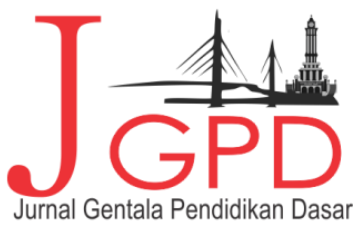

JURNAL GENTALA PENDIDKAN DASAR Vol.5 No. I Juni 2020, Halaman 91-I09 P-ISSN : 2614-7092, E-ISSN : 2621-96II

Terbit Online Pada Laman Web : hittp://online-journal.unja.ac.id/index.php/gentala email : penyunting.jurnal.g-pgsd国unja.ac.id

siklus selanjutnya yaitu siklus II dan menguatkan penggunaan model inkuiri. Kekurangan dan ketidakmampuan menerapkan model pembelajaran inkuiri menjadi faktor utama belum tercapainya kriteria keberhasilan.

Pada siklus kedua siswa mengalami peningkatan dari nilai sikus pertama. Adanya peningkatan kemampuan matematis siswa ini karena dipengaruhi oleh adanya peningkatan kemampuan siswa dalam memahami pembelajaran dengan model inkuiri. Disamping itu peningkatan kemampuan guru dalam mengelola pengajaran dengan model inkuiri semakin mantap.

Perubahan perbaikan dari siklus II ke siklus III semakin membaik ,hal ini disebabkan karena guru mulai terbiasa menggunakan model inkuiri ini. Hal ini terlihat dari keterampilan guru menggunakan langkah-langkah model inkuiri guru sudah semakin membaik, sehingga siswa juga semakin berminat untuk belajar. Pembagian waktu sudah semakin terorganisir. Pengelolaan kelas mengalami perubahan ke arah yang lebih teratur, siswa mulai tertarik dengan suasana pembelajaran yang baru. Situasi ini akan meningkatkan minat siswa untuk belajar Matematika yang pada akhirnya mempengaruhi hasil belajar ke arah yang lebih baik.

Dari data-data yang telah diperoleh dapat diuraikan sebagai berikut:

1) Selama proses belajar mengajar guru telah melaksanakan semua pembelajaran dengan baik. Meskipun ada beberapa aspek yang belum sempurna, tetapi persentase pelaksanaannya untuk masing-masing aspek cukup besar.

2) Berdasarkan data hasil pengamatan diketahui bahwa siswa aktif selama proses belajar berlangsung.

3) Kekurangan pada siklus-siklus sebelumnya sudah mengalami perbaikan dan peningkatan sehingga menjadi lebih baik.

4) Hasil belajar siswsa pada siklus kedua mencapai ketuntasan.

Pada siklus ketiga ini guru telah menerapkan pembelajaran dengan model inkuiri dengan baik dan dilihat dari aktivitas siswa serta hasil belajar siswa. Maka tindakan selanjutnya adalah memaksimalkan dan mempertahankan apa yang telah ada dengan tujuan agar pada pelaksanaan proses belajar mengajar selanjutnya penerapan pembelajaran dengan model inkuiri dapat meningkatkan proses belajar mengajar sehingga tujuan pembelajaran dapat tercapai. 


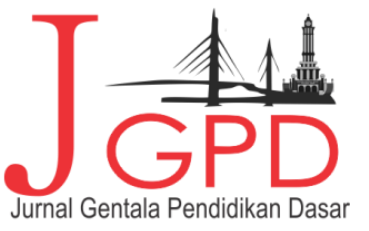

JURNAL GENTALA PENDIDIKAN DASAR Vol.5 No. I Juni 2020, Halaman II-I09 P-ISSN : 2614-7092, E-ISSN : 2621-9611

Terbit Online Pada Laman W eb : http://unline-juurnal.unja.ac.id/index.php/gentala email : peny unting.jurnal.g-pgsd国unja.ac.id

Melalui hasil penelitian ini menunjukkan bahwa pembelajaran dengan menggunakan model inkuiri memiliki dampak positif dalam meningkatkan hasil belajar siswa.Hal ini dapat dilihat dari semakin mantapnya pemahaman dan penguasaan siswa terhadap materi yang telah disampaikan guru. Berikut dapat dilihat rekapitulasi hasil belajar siswa dari kondisi awal, siklus pertama dan siklus kedua pada tabel di bawah ini :

\section{Tabel 5. Rekapitulasi Hasil Kemampuan Matematis Pada Materi Pengolahan Data}

\begin{tabular}{|c|l|c|c|c|}
\hline \multirow{2}{*}{ No } & \multirow{2}{*}{ Aspek yang dinilai } & \multicolumn{3}{|c|}{ Jumlah atau Persentase } \\
\cline { 3 - 5 } & & Siklus I & Siklus II & Siklus III \\
\cline { 3 - 5 } & & Rata-rata & Rata-rata & Rata-rata \\
\hline 1 & Rata-rata & 69,56 & 73,71 & 74,85 \\
\hline 2 & Jumlah siswa yang tuntas & 21 & 25 & 28 \\
\hline 3 & Jumlah siswa yang tidak tuntas & 11 & 7 & 4 \\
\hline 4 & Persentase ketuntasan siswa & $66 \%$ & $78 \%$ & $88 \%$ \\
\hline 5 & $\begin{array}{l}\text { Persentase siswa yang tidak } \\
\text { tuntas }\end{array}$ & $34 \%$ & $22 \%$ & $12 \%$ \\
\hline
\end{tabular}

\section{KESIMPULAN DAN IMPLIKASI}

Dari hasil kegiatan pembelajaran yang telah dilakukan di atas dan berdasarkan seluruh pembahasan serta analisis yang telah dilakukan dapat disimpulkan bahwa pembelajaran dengan penggunaan model inkuiri memiliki dampak positif dalam meningkatkan kemampuan matematis siswa yang ditandai dengan peningkatan ketuntasan belajar siswa dalam setiap pembelajaran yaitu pada siklus pertama (66 \%), siklus kedua (78 \%), dan siklus ketiga (88 $\%)$.

Adapun saran pada penilitian tindakan kelas ini sebagai berikut:

(a) Untuk melaksanakan pembelajaran dengan menggunakan model inkuiri memerlukan persiapan yang cukup matang, sehingga guru harus mampu menentukan atau memilih topik yang benar-benar bisa diterapkan dengan penggunaan model inkuiri dalam proses belajar mengajar sehingga diperoleh hasil yang optimal.

(b) Dalam rangka meningkatkan hasil belajar siswa, guru hendaknya lebih sering melatih siswa dengan berbagai metode pembelajaran yang variatif dan yang sesuai, walau dalam taraf yang sederhana, dimana siswa nantinya dapat menemukan pengetahuan 


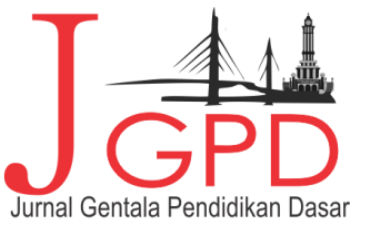

JURNAL GENTALA PENDIDIKAN DASAR Vol.5 No. I Juni 2020, Halaman II-I09 P-ISSN : 2614-7092, E-ISSN : 2621-S6611

Terbit Online Pada Laman Web : http://online-juurnal.unja.ac.id/index.php/gentala email : peny unting.jurnal.g-pgsd回unja.ac.id

baru, memperoleh konsep dan keterampilan, sehingga siswa berhasil atau mampu memecahkan masalah-masalah yang dihadapinya.

(c) Perlu adanya penelitian yang lebih lanjut, karena hasil penelitian ini hanya dilakukan di SD Negeri 61/X Talang Babat di tahun pembelajaran 2018/2019.

(d) Untuk penelitian yang serupa hendaknya dilakukan perbaikan-perbaikan agar diperoleh hasil yang lebih baik.

\section{DAFTAR PUSTAKA}

Arikunto, Suharsini. 2008. Dasar-Dasar Evaluasi Pendidikan. Jakarta : Bumi Aksara.

Daryanto. 2015. Strategi dan Tahapan Mengajar bekal Keterampilan Dasar BagiGuru. Bandung:CV. Yrama Widia.

Dasna I Wayan. 2013. Penelitian Tindakan Kelas. Malang: Universitas Negeri Malang.

Dimyati, \& Mujiono. 2006. Belajar dan Pembelajaran. Jakarta : PT. Renika Cipta

Djaali H 2009. Psikologi Pendidikan. Jakarta:PT. Buana Aksara.

Erlangga. 2016. ESPS Matematika Untuk SD Kelas V. Jakarta : Erlangga..

Kurniasih, Imas. dan Sani, Berlin. 2016. Model pembelajaran. Kata Pena.

Karso.2002.Pendidikan Matematika I( Cet ke 5): Universitas Terbuka

Muslich, Masnur. 2009. Melaksanakan PTK Itu Mudah.Jakarta : PT. Bumi Aksara.

Muhsetyo,Gatot dkk. 2010. Pembelajaran Matematika SD.Jakarta:Unversitasi

Terbuka.

Noeraida, dkk. 2016. Teori Belajar dan Implementasinya Dalam Pembelajaran. Jakarta : Kemdikbud.

Permendiknas Nomor 57 Tahun 2014

Saefuddin, Asis. dan Berdianti, Ika. 2014. Pembelajaran Efektif. Bandung : PT. Remaja Rosdakarya.

Sanjaya, Wina. 2013. Strategi Pembelajaran Berorientasi Standar Proses Pendidikan.Jakarta : Kencana Prenadamedia Grup

Sukardi. 2010. Metodologi Penelitian Pendidikan. Jakarta : PT. Bumi Aksara.

Susanto, Ahmad. 2014. Teori Belajar dan Pembelajaran di SD. Jakarta : kencana Prenadamedia Grup.

Winaputra, Udin S. 2001. Model Pembelajaran. Jakarta : Pusat PenerbitanUniversitas Terbuka.

Zubaidah, Siti dkk. 2013. Model dan Metode Pembelajaran SMP IPA. Malang : Universitas Negeri Malang. 